\title{
Contact Call-Driven Zenk Protein Induction and Habituation in Telencephalic Auditory Pathways in the Budgerigar (Melopsittacus Undulatus): Implications For Understanding Vocal Learning Processes
}

\author{
Steven Brauth, ${ }^{1,3}$, Wenru Liang, ${ }^{1}$ Todd F. Roberts, ${ }^{1}$ Lindsey L. Scott, ${ }^{2}$ \\ and Elizabeth M. Quinlan ${ }^{2}$ \\ Departments of ${ }^{1}$ Psychology and ${ }^{2}$ Biology, University of Maryland, College Park, Maryland 20742, USA
}

\begin{abstract}
Expression of the immediate early gene protein Zenk (zif 268, egr-1, NGF1A, Krox24) was induced in forebrain auditory nuclei in a vocal learning parrot species, the budgerigar (Melopsittacus undulatus), when the subjects either listened to playbacks of an unfamiliar contact call or to a contact call with which they had been familiarized previously. Auditory nuclei included the Field L complex (L1, L2a, and L3), the neostriatum intermedium pars ventrolateralis (NIVL), the neostriatum adjacent to caudal nucleus basalis (peri-basalis or pBas), an area in the frontal lateral neostriatum (NFI), the supracentral nucleus of the lateral neostriatum (NLs), and the ventromedial hyperstriatum ventrale (HVvm). The latter three nuclei are main sources of auditory input to the vocal system. Two patterns of nuclear staining were induced by contact call stimulation-staining throughout cell nuclei, which was exhibited by at least some neurons in all areas examined except L2a and perinucleolar staining, which was the only kind of staining exhibited in field L2a. The different patterns of Zenk staining indicate that auditory stimulation may regulate the Zenk-dependent transcription of different subsets of genes in different auditory nuclei. The numbers of neurons expressing Zenk staining increased from seven- to 43-fold over control levels when the birds listened to a repeating unfamiliar call. Familiarization of the subjects with the call stimulus, through repeated playbacks, greatly reduced the induction of Zenk expression to the call when it was presented again after an intervening 24-h interval. To determine if neurons exhibiting contact call-driven Zenk expression project to the vocal control system, call stimulation was coupled with dextran amines pathway tracing. The results indicated that tracer injections in the vocal nucleus HVo (oval nucleus of the hyperstriatum ventrale), in fields lateral to HVo and in NLs labeled many Zenk-positive neurons in HVvm, NFl, and NLs. These results support the idea that, in these neurons, egr-1 couples auditory stimulation to the synthesis of proteins involved in either the storing of new perceptual engrams for vocal learning or the processing of novel and/or meaningful acoustic stimuli related to vocal learning or the context in which it occurs.
\end{abstract}

It is generally believed that the long-term changes in synaptic strength necessary for the maintenance of memories require protein synthesis controlled by the expression of immediate early genes (IEGs) (Kaczmarek and Chaudhuri 1997; Lerea 1997; Herdegen and Leah 1998; O'Donovan et al. 1999; Tischmeyer and Grimm 1999; Clayton 2000). The discovery that expression of the immediate early gene egr-1 occurs under the same physiological conditions as longterm potentiation in the hippocampal perforant path has strengthened the idea that $e g r-1$ expression is causally related to synaptic plasticity (O'Donovan et al. 1999). In songbirds, the homologous gene called zenk (zif268, egr-1,

${ }^{3}$ Corresponding author.

E-MAIL brauth@psyc.umd.edu; FAX (301) 314-9566.

Article and publication are at http://www.learnmem.org/cgi/doi/ $10.1101 / 1 \mathrm{~m} .40802$.
$\underline{N G F 1 A}$, and $\underline{\text { Krox } 24)}$ ) is expressed in higher order auditory nuclei (i.e., the caudomedial neostriatum) in response to novel conspecific song, including playbacks of the bird's own song, but not other kinds of acoustic stimuli (Mello et al. 1992; Jarvis et al. 1995; Ribiero et al. 1998). Furthermore, zenk expression in songbirds habituates with repeated exposure to novel stimuli and can be reinstated by exposure to novel song, implying that zenk expression is related to encoding new information in this system (Mello et al. 1995) or to enhancing memory formation processes (Clayton 2000). The success of these methods in exploring the functional organization of auditory-vocal circuits in songbirds implies that mapping auditory-driven zenk induction and habituation might be used as a tool for exploring the functional organization of auditory pathways in other avian vocal learning species. In this study, we used these methods to

LEARNING \& MEMORY 9:76-88 @ 2002 by Cold Spring Harbor Laboratory Press ISSN1072-0502/02 \$5.00

$$
\begin{array}{lllllllllllllll} 
& E & A & R & N & I & N & G & \& & M & E & M & O & R & Y \\
\text { www.learnmem.org } & & &
\end{array}
$$


study auditory pathways in a vocal learning parrot species, the budgerigar (Melopssitcaus undulatus).

In birds, two ascending pathways called the thalamocortical and isthmofrontal pathways convey auditory information from the brainstem to the telencephalon (Arends and Zeigler 1986; Brauth et al. 1987, 1994; Hall et al. 1993; Wild et al. 1993, 1996; Striedter 1994; Wild and Farabaugh 1996). The thalamocortical pathway involves projections from the inferior colliculus (nucleus mesencephalic lateralis pars dorsalis) to the thalamic auditory relay, nucleus ovoidalis (Ov) (Karten 1967). Ov projects to the granule cell layer of Field L (i.e., L2a) of the caudomedial telencephalon (Karten 1968; Brauth et al. 1987; Wild et al. 1993). This pathway is similar to the primary auditory pathway of mammals from the medial geniculate nucleus to the primary auditory areas of the temporal lobe (Butler and Hodos 1996).

The avian isthmofrontal auditory pathway has no direct counterpart in mammals. This pathway involves direct projections from the intermediate nucleus of the lateral lemniscus to a nucleus in the anterior telencephalon called nucleus basalis (Bas) (Arends and Zeigler 1986; Hall et al. 1993; Striedter 1994; Wild and Farabaugh 1996). In budgerigars, the thalamocortical and isthmofrontal pathways interact (Farabaugh and Wild 1997). Neurons in the L1 and L3 lamina of Field $\mathrm{L}$ as well as neurons in the auditory Bas both project to a circumscribed area that, in budgerigars, has been termed NFl (frontal lateral neostriatum) (Striedter 1994) or the lateral nucleus of the anterior neostriatum (1AN) (Jarvis and Mello 2000). Of particular importance for this study is the fact that NFl/1AN neurons subsequently project to areas that have been shown to be anatomically related to the vocal control system in budgerigars (Brauth et al. 2001).

The main auditory pathways related to the budgerigar vocal control system are illustrated schematically in Figure 1. As shown, NFI (= 1AN), the supracentral nucleus of the lateral neostriatum (NLs), and ventromedial hyperstriatum ventrale $(\mathrm{HVvm})$ provide the main input to the vocal control system in this species. This input stream is mediated by two vocal control nuclei, the oval nucleus of the hyperstriatum ventrale (HVo) and the central nucleus of the lateral neostriatum (NLc). The NFl/1AN receives input from the caudal part of the nucleus basalis (Bas) as well as from Field L (Farabaugh and Wild 1997). Neurons in NFl project to NLs (Striedter 1994), which, in turn, projects to NLc and HVo (Brauth et al. 2001). In addition, the neostriatum immediately lateral to the caudal part of Bas (i.e., peri-basalis or pBas) projects directly to HVo (Brauth et al. 2001). NLc and HVo, in turn, project to other vocal control nuclei including those that project to the brainstem (Striedter 1994) as well as to a basal ganglia nucleus, the magnicellular nucleus of the lobus parolfactorius (LPOm) (Durand et al. 1997). HVvm receives input from the neostriatum intermedium

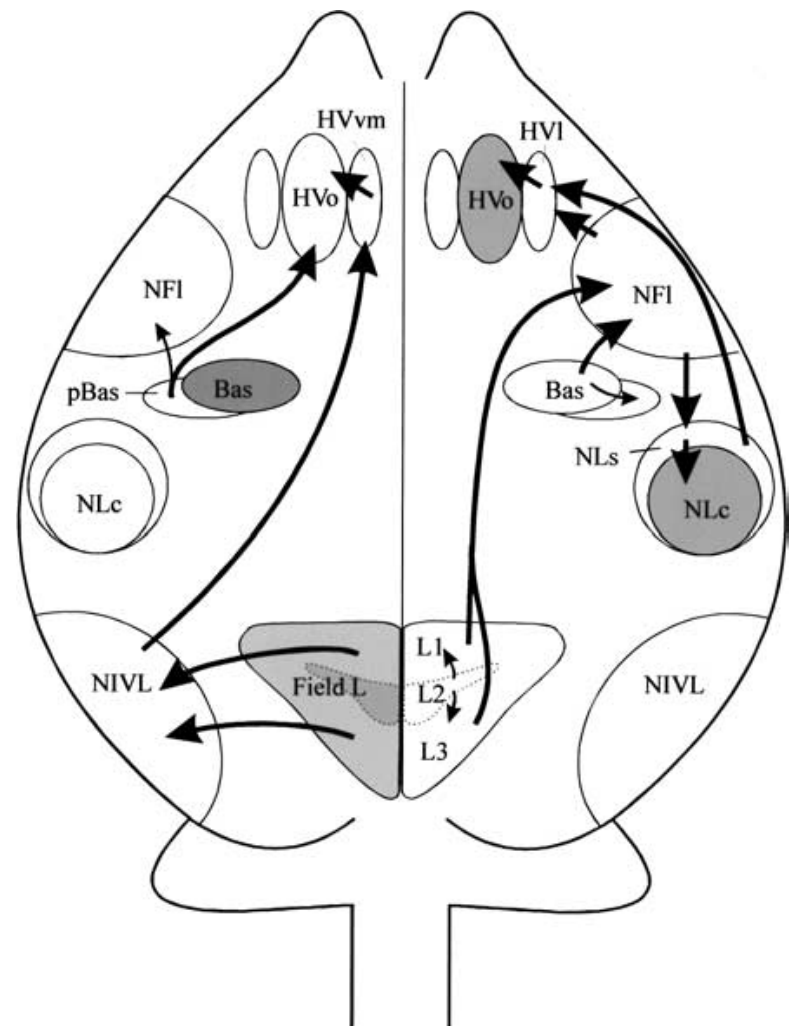

Figure 1 A schematic drawing of the budgerigar telencephalon in the horizontal plane indicating the main auditory pathways related to the vocal control system. Pathways reaching the HVvm and HVo are indicated schematically on the left hemisphere of the drawing, whereas those reaching the NFI/IAN, NLs, and lateral HVo surround $(\mathrm{HVvl})$ are indicated schematically on the right hemisphere. Note that although the schematic drawing is rendered in the horizontal plane, all other anatomical drawings are shown in transverse section. Shaded structures on the right side of the drawing are vocal control nuclei as defined by previous studies (Striedter 1994; Durand et al. 1997). Shaded structures on the left side of the drawing are auditory nuclei as defined by previous studies (Brauth and McHale 1988; Striedter 1994; Farabaugh and Wild 1997).

pars ventrolateralis (NIVL), a higher-order auditory nucleus that receives input from Field L (Brauth and McHale 1988; Hall et al. 1993).

In oscine songbirds, only the thalamocortical auditory system has been linked to the song control system. Field L has been shown to project to a shelf region underlying a vocal control nucleus, the high vocal center or HVC (Kelley and Nottebohm 1979: Fortune and Margoliash 1995; Vates et al. 1996; Wild and Farabaugh 1996). Field L neurons also project to neurons in the caudomedial neostriatum (NCM), which project to portions of the caudal hyperstriatum ventrale. Neurons in the caudal hyperstriatum ventrale project to both the HVC shelf and a cup region near the robust nucleus of the archistriatum. HVC, in turn, gives rise to projections to other vocal nuclei including the robust nucleus of the archistriatum, which projects to brainstem vocal control nuclei and to Area $\mathrm{X}$, a specialized nucleus

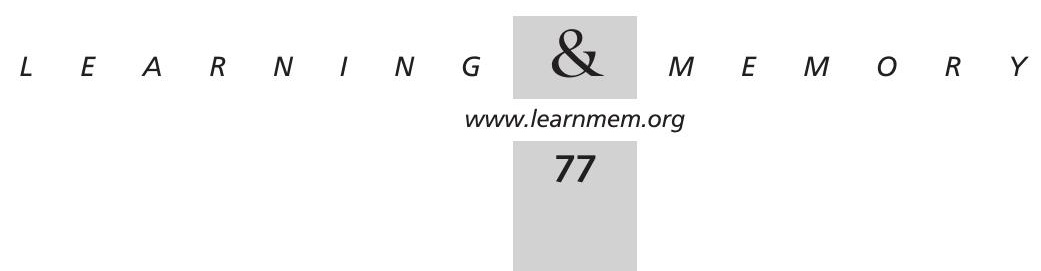


within the lobus parolfactorius (LPO) essential for acquisition of learned sounds during the sensitive period early in life (Bottjer et al. 1984). In contrast to auditory pathways in budgerigars, pathway tracing studies (Wild and Farabaugh 1996) have failed to find connections between nucleus Bas or its projection targets and the song system in the zebra finch.

Vocal learning is thought to have evolved independently in at least three orders of birds including oscine songbirds, psittacines. and apodiformes (Striedter 1994; Gahr 2000; Jarvis and Mello 2000; Jarvis et al. 2000). Therefore, it is not surprising to find anatomical differences in the ways that forebrain pathways are organized. These differences may also reflect differences in how auditory feedback is processed and conveyed to the vocal system during vocal learning, however, pathway tracing alone cannot prove that this is the case. In songbirds, demonstration of the rapid induction and habituation of zenk mRNA in Field L and in adjacent portions of the caudomedial neostriatum (NCM) by song (Mello et al. 1995) and song-specific syllables (Ribiero et al. 1998) supports the idea that in these species perceptual learning processes necessary for vocal learning depend on neuronal activity in Field L and NCM. To gain insight into the functional organization of auditory pathways in the budgerigar, we mapped out contact call-driven Zenk protein induction and habituation throughout the auditory system.

In a previous study, Jarvis and Mello (2000) showed that warble stimulation, in the absence of vocalization, induced zenk mRNA expression in Field L and NCM in budgerigars. In this study, we used repeating contact calls as the stimuli to study Zenk protein expression. This stimulus was selected because both males and females readily learn contact calls in social situations and because contact calls are the predominant call of budgerigars (Farabaugh et al. 1994; Hile et al. 2000). Furthermore, little attention has been given to the genomic responses to species-typical calls in either songbirds or parrots. We measured the staining of auditory nuclei for Zenk protein as an indicator of IEG-regulated transcription in the auditory system. Therefore, this study breaks new ground by measuring call-driven IEG protein expression in the auditory system of a vocal learning species.

This study was carried out with three aims in mind. First, we sought to determine if neurons in the auditory areas identified above (see Fig. 1), exhibit Zenk protein induction in response to stimulation with a repeating unfamiliar contact call. Second, we sought to determine if Zenk protein induction in these areas was attenuated when the birds were familiarized with a previously unfamiliar contact call through repeated playbacks of the call. Zenk induction is thought to be strongly dependent on the novelty and/or meaningfulness of a stimulus in a particular context (Jarvis et al. 1995; Mello et al. 1995) and habituates rapidly when stimulus novelty or the information content of a stimulus decreases. Therefore, the induction and habituation of Zenk protein expression can be used to identify potential neural circuits participating in perceptual learning. Finally, we combined Zenk protein immunohistochemistry with pathway tracing to determine if neurons in
A
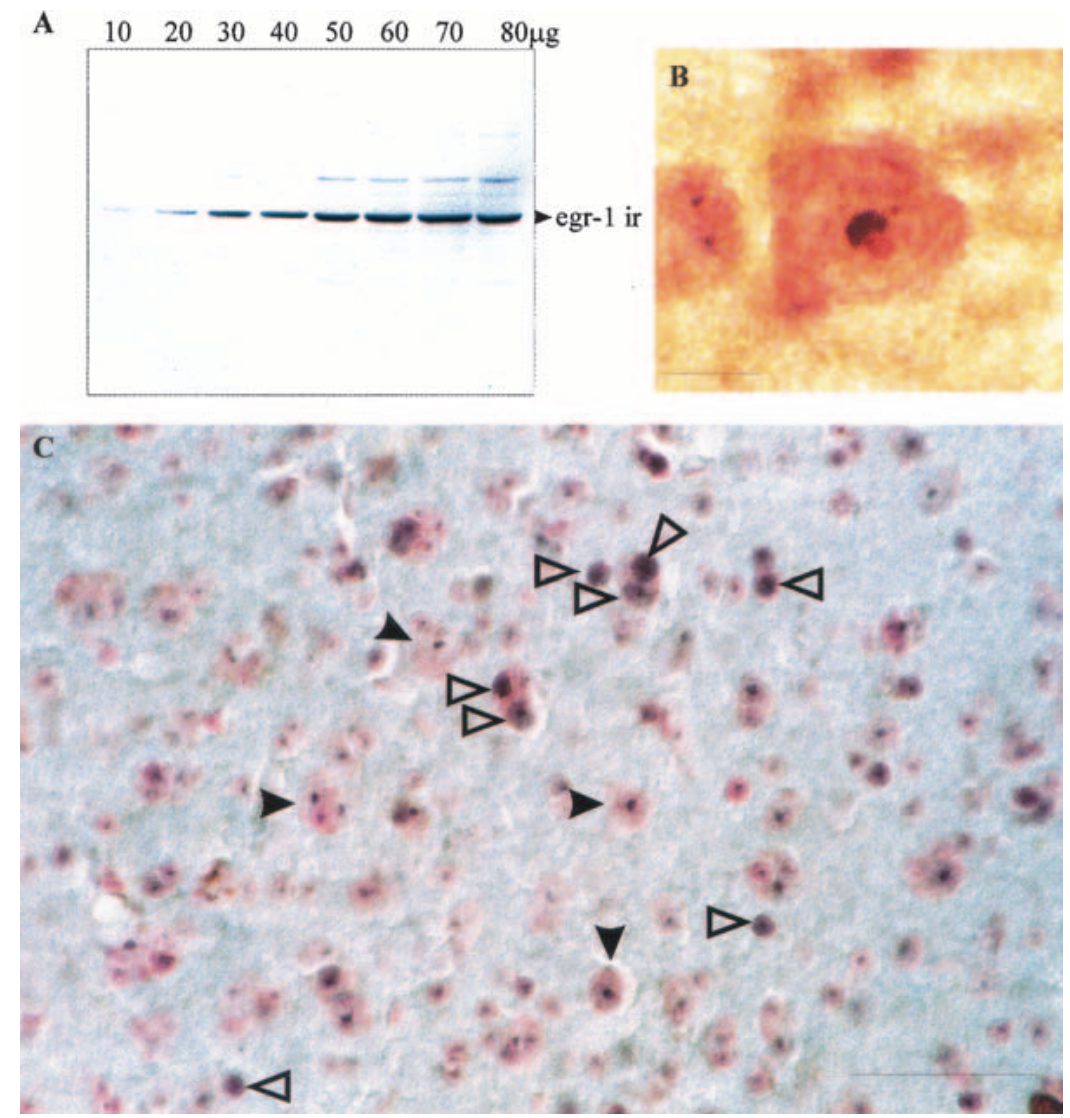

Figure 2 (A) Representative immunoblot for budgerigar egr-1 derived from cytoplasmic proteins of Field $\mathrm{L}$ tissue collected after auditory stimulation with a repeating unfamiliar contact call. The egr-1 band has the same electrophoretic mobility ( 73 kD) as predicted from previous studies. $(B)$ Photograph illustrating one cell in which only perinucleolar Zenk staining is present in the cell nucleus. Zenk protein immunolabel is stained using the blue SG chromogen and counterstained with neutral red. Note that the nucleolus is clearly visible adjacent to stained portion of the nucleus. (C) Photomicrograph of stained tissue section from NFI/IAN depicting Zenk particles stained with the blue SG chromogen and counterstained with neutral red. Both whole nuclear and small perinucleolar stained areas are present (see text). Open arrowheads point to cells containing perinucleolar staining. Solid arrows point to cells containing whole nuclear staining. Scale bar, $10 \mu \mathrm{m}$ in $B ; 40 \mu \mathrm{m}$ in $C$.

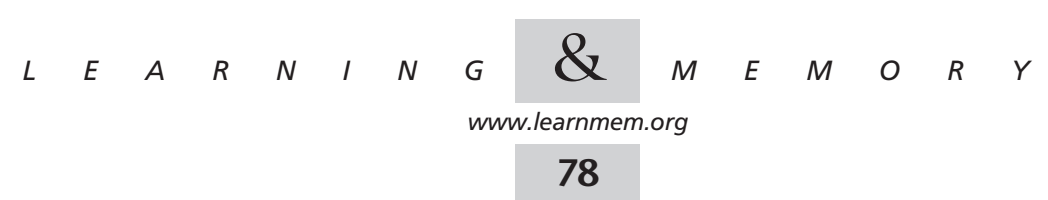


the NFl /1AN, NLs, and HVvm that project to the vocal control system express contact calldriven Zenk protein expression.

\section{RESULTS}

\section{Antibody Specificity and Nuclear Staining Patterns}

Immunoblot analysis of cytoplasmic proteins following nuclear lysis from budgerigar telencephalon (including the Field $\mathrm{L}$ area) after $1 \mathrm{~h}$ of stimulation with an unfamiliar contact call was performed to examine the specificity of the egr-1 antibody used for immunohistochemistry. The results of one representative immunoblot is provided in Figure 2A. As shown, the antibody labels a band with an electrophoretic mobility of $73 \mathrm{kD}$ (Waters et al. 1990). No significant cross-reactivity with other proteins was observed. In addition, immunocytochemical staining was completely blocked when the antibody was preabsorbed with the cognate egr-1 peptide. Preabsorption with $s p 1$, an immediate early gene with overlapping substrate specificity (Lei and Heckert 2002) had no effect on egr1 staining (data not shown). Together, these data indicate that the antibody specifically recognizes the Zenk protein.

Using this antibody, two different nuclear staining patterns were induced by contact calls. In many neurons (see Fig. 2B,C), staining was observed throughout the nucleus. In some neurons, however, dense staining immediately adjacent to the nucleolus was observed (see Fig. 2B). In a few brain areas, including Field L2a, L2b, and the ectostriatum, only perinucleolar staining was observed; in all other areas studied here both kinds of labeling were observed.

\section{General Patterns of Zenk \\ Protein Distribution}

There was very little Zenk expression in the brains of control subjects consistent with the work of Jarvis and Mello (2000); these results are not illustrated for this reason. The general pattern of Zenk protein labeling in the telencephalon for a subject who listened to a repeating contact call for $60 \mathrm{~min}$ is presented in Figures 3 and 4. In Figure 3, panels A-C show line drawings indicating schematically the distribution of cells with labeled nuclei in the caudal telencephalon, whereas panels D-F
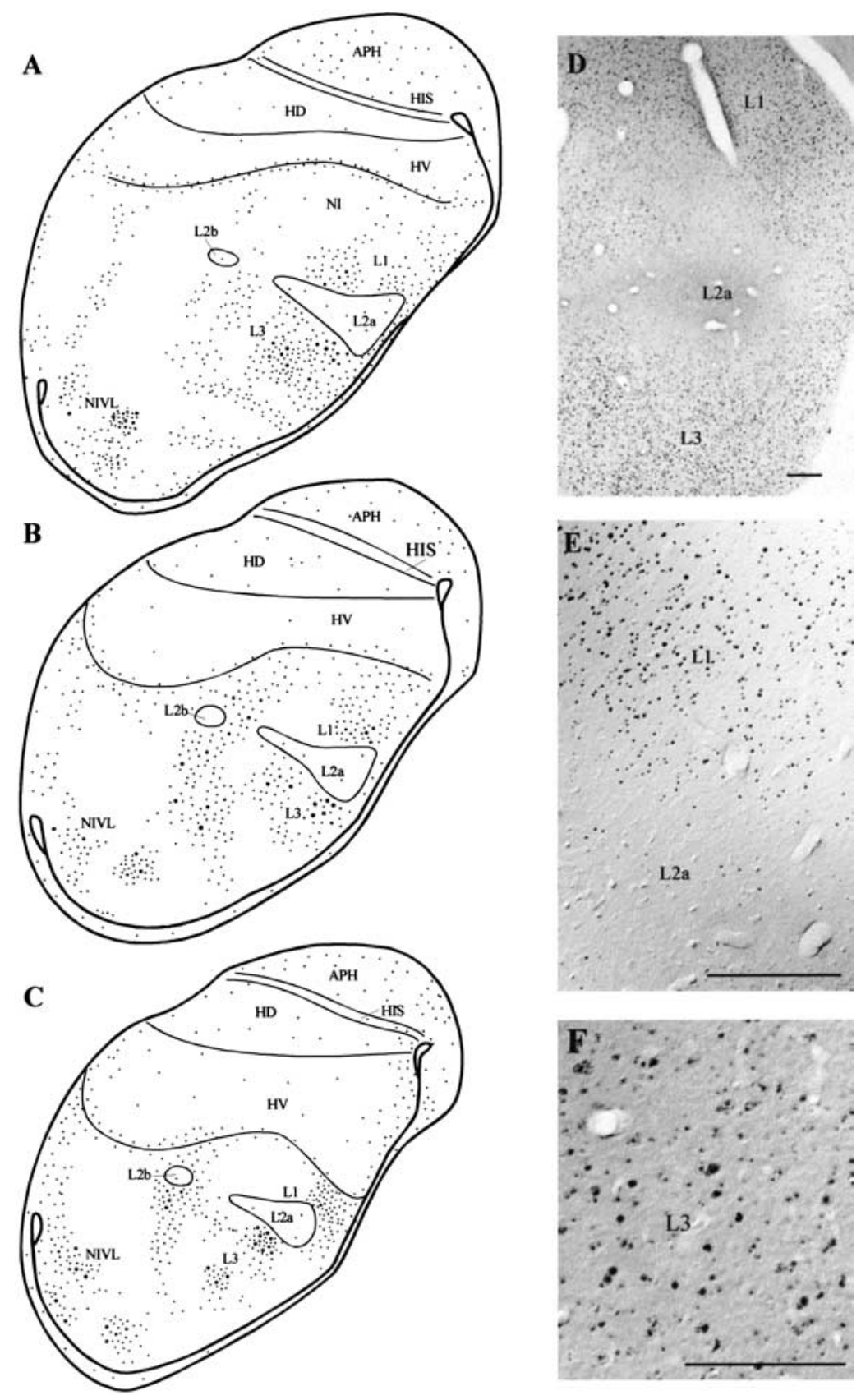

Figure 3 Schematic drawings arranged in rostrocaudal sequence $(A-C)$ and photomicrographs $(D-F)$ illustrating patterns of Zenk staining in the caudal telencephalon at the level of Field L and NIVL. Each dot in the line drawings represents three to five labeled nuclei. Small dots indicate fine particles such as those present in L2a and as shown in D and E. Large dots are large particles in cell nuclei as illustrated in E and F for L1 and L3. Note that while small perinucleolar zenk particles are difficult to visualize in Field L2a at low power using a 5X objective lens (E), these particles are clearly visible at higher power using a 20X objective lens (F). Many such perinucleolar particles can be visualized in Field L2a using a 100X oil immersion objective as described in the text. Scale bar in both $D$ and $E, 200 \mu \mathrm{m}$. Scale bar in F, $100 \mu \mathrm{m}$.

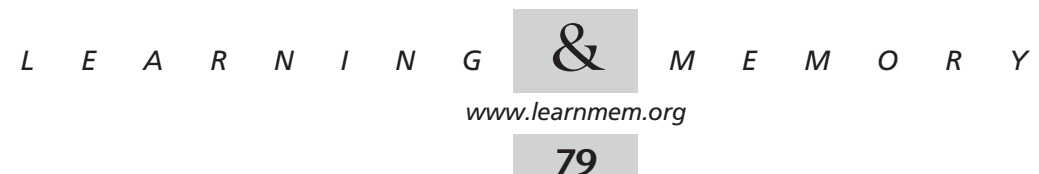




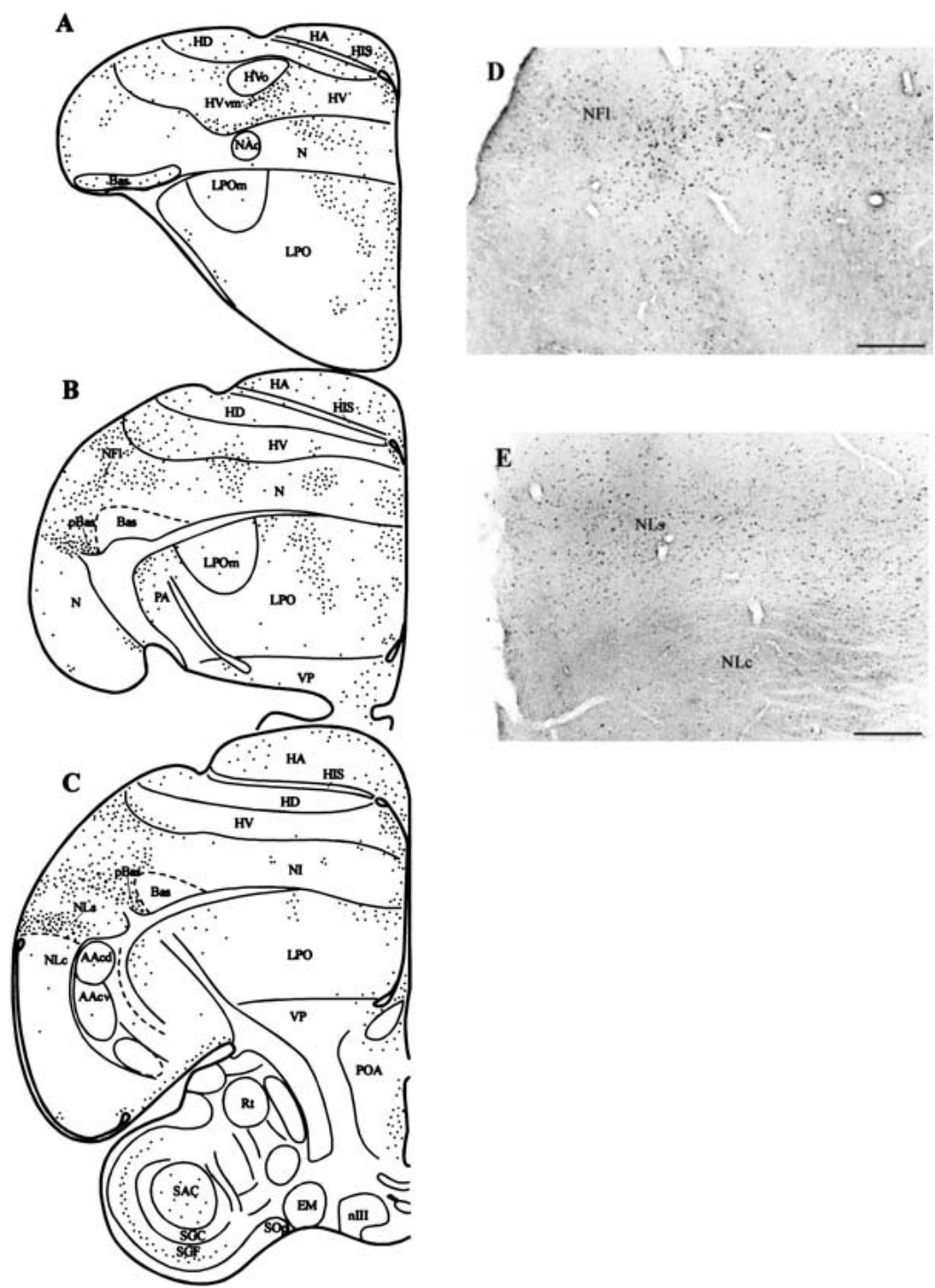

Figure 4 Schematic drawings $(A-C)$ arranged in rostrocaudal sequence illustrating the distribution of Zenk-positive neurons in the anterior telencephalon at the level of the $\mathrm{HV} v \mathrm{~m}, \mathrm{NFI} / \mathrm{IAN}, \mathrm{pBas}$, and NLs. Many neurons in these areas contained labeled nuclei. Fig. 5D,E are photomicrographs illustrating patterns of Zenk staining in NFI $(D)$ and NLs $(E)$. Note the sharp cutoff in Zenk staining at the border of NLs and NLc $(E)$. Scale bar in $D$ and $E, 200 \mu \mathrm{m}$.

are photomicrographs derived from these sections. As can be seen in Figure 3, there was relatively little Zenk staining in Field L2a, although some cells did express small perinucleolar particles (see Fig. 3D,E). In contrast, fields L1 and L3 contained many neurons expressing Zenk protein (see Fig. 3A-C). Zenk staining in neurons in Fields L1 and L3 involved staining throughout the whole nucleus, although both whole nuclear and perinucleolar staining were observed.

Note that although the distribution of Zenk+-labeled cells in Field $\mathrm{L}$ is patchy, three major bands or zones are evident. The most medial zone includes L1 and L3 and extends more dorsally and ventrally. The second band of Zenk+-labeled cells lies dorsal and ventral to the L2b nucleus. The most lateral band of Zenk+ neurons includes the NIVL (neostriatum intermedium pars ventrolateralis), a higher-order auditory region (Brauth and McHale 1988; Brauth et al. 1994) that receives input from Field L and provides input to the HV medial to HVo (Hall et al. 1993; Brauth et al. 2001) (see Discussion).

Zenk staining at the level of the anterior telencephalon for the same case is depicted in Figure 4. As can be shown in Figure 4, panels A-C, many neurons in the NFl and NLs expressed Zenk in this experiment. Both whole nuclear and perinucleolar staining was observed in these areas although most neurons exhibited staining throughout the nucleus (see Fig. 4D,E). Zenk staining in the neostriatum immediately adjacent to the caudal nucleus basalis (pBas) was also substantial and many neurons in this area contained staining throughout the nucleus. In addition, the medial HV adjacent to HVo (HVvm) contained many neurons exhibiting Zenk staining, although many of these cells exhibited only perinucleolar staining.

Note that Zenk staining was quite low in all vocal control nuclei including HVo, the medial oval nucleus of the anterior neostriatum (NAom), the oval nucleus of the anterior neostriatum (NAo), LPOm, NLc, and AAc, consistent with the work of Jarvis and Mello (2000). Nevertheless, some neurons in all vocal nuclei were observed to exhibit perinucleolar Zenk staining. For example, as shown in Figure 4E, Zenk staining in NLs cuts off quite sharply at the boundary of NLs and NLc, although some neurons in NLc do express Zenk protein under the conditions of the experiment as evidenced by the scattered distribution of perinucleolar staining in neurons within NLc in this case.

\section{Quantitation of Zenk Protein Expression}

Figure 5 presents the density of neurons containing nuclear Zenk protein in Fields L1, L2a, L3, NIVL, pBas, NFl/1AN, NLs, and $\mathrm{HVvm}$ as a function of stimulation condition based on stereological counting methods (Coggeshall and Lekan 1996).

Figure $5 \mathrm{~A}$ depicts the results of the induction proce-

$$
\begin{array}{lllllllllllllll}
L & E & A & R & N & I & N & G & \& & M & E & M & O & R & Y \\
\text { www.learnmem.org } & & &
\end{array}
$$




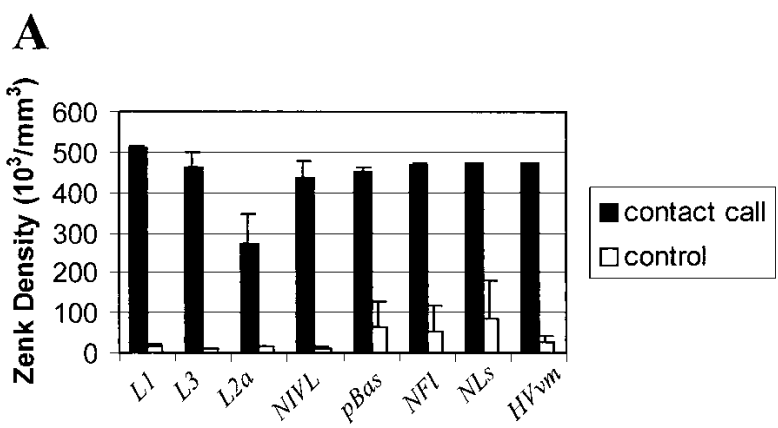

B

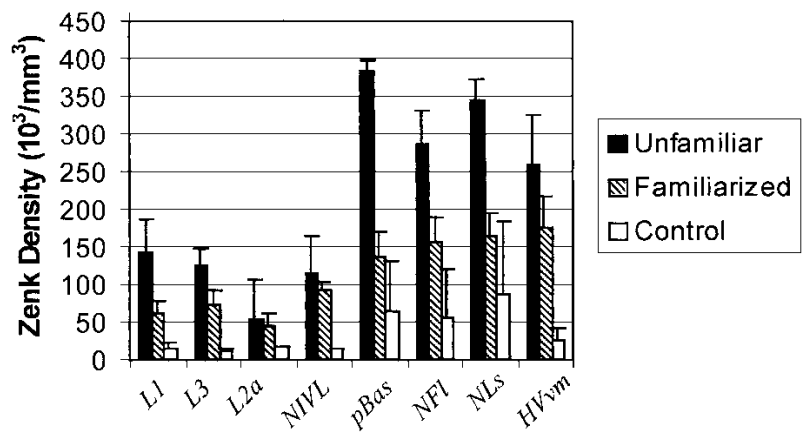

Figure 5 (A) Chart indicating Zenk density in particles $\times 10^{3} / \mathrm{mm}^{3}$ in L1, L3, L2a, NIVL, pBas, NFI, NLs, and HVvm for subjects experiencing a repeating unfamiliar contact call for 30 min followed by a 60 -min rest period and for subjects experiencing no stimulation (control). (B) Chart indicating Zenk density in particles $\times 10^{3}$ / $\mathrm{mm}^{3}$ in L1, L3, L2a, NIVL, pBas, NFI, NLs, and HVvm for birds listening to a repeating unfamiliar contact call for $60 \mathrm{~min}$ and for birds listening to the same call for $60 \mathrm{~min}$ after having been familiarized previously with the call $2 \mathrm{~d}$ earlier.

dure in which a repeating contact call was presented for 30 min and the birds then allowed to rest quietly for $60 \mathrm{~min}$. Figure 5B depicts the results of the habituation procedure in which the subjects were first familiarized with a previously unfamiliar call, rested for $24 \mathrm{~h}$ and then presented with the same call for $60 \mathrm{~min}$ before being anesthetized and processed for Zenk immunohistochemistry.

As shown in Figure 5A, all structures showed a profound increase in Zenk expression from seven- to 43-fold as a function of auditory stimulation. The differences for all structures between stimulation and control conditions were statistically significant at or better than the 5\% confidence level $(P<0.001$ for Field L1; $P=0.003$ for L3; $P=0.039$ for L2a; $P=0.005$ for NIVL; $P=0.015$ for pBas; $P=0.012$ for NFl/lAN; $P=0.029$ for NLs; and $P=0.001$ for HVvm). It should be noted that although the density of neurons in field L2a increased substantially as a function of stimulation, all labeled neurons contained only perinucleolar staining.

Figure 5B depicts the results of the familiarization procedure. All structures showed reductions in Zenk protein expression as a result of familiarization with the call stimu- lus, but the reductions for L2a and NIVL were not statistically significant using MANOVA $(P=0.047$ for L1; $P=0.042$ for L3; $P=0.797$ for L2a; $P=0.463$ for NIVL; $P<0.001$ for pBas; $P=0.013$ for NFl/lAN; $P=0.002$ for NLs; and $P=0.049$ for $\mathrm{HVvm}$ ). Stimulation for $60 \mathrm{~min}$ yielded significantly less protein expression than stimulation for $30 \mathrm{~min}$ followed by a 60 -min rest $(P=0.002$ for L1; $P=0.001$ for L3; $P=0.028$ for L2a; $P=0.005$ for NIVL; $P=0.009$ for pBas; $P=0.011$ for NFl/lAN; $P=0.008$ for NLs; and $P=0.023$ for $\mathrm{HVvm}$ ), consistent with the idea that protein expression peaks within $2 \mathrm{~h}$ after stimulation and likely was still increasing in the animals exposed to auditory stimulation for $60 \mathrm{~min}$ (Clayton 2000).

\section{Results of Pathway Tracing Experiments}

Only scattered Zenk-labeled neurons were observed in the areas of the telencephalon that contained backfilled cells in the two control cases and no backfilled cells contained Zenk-labeled nuclei. These cases are not illustrated for this reason. The results of three other cases are illustrated in Figures 6,7, and 8 .

Figure 6 depicts the results of a BDA experiment in which the tracer was injected into the hyperstriatum ventrale (HV) immediately lateral to HVo (i.e., the lateral HVo surround) (see Fig. 6A,D). Auditory stimulation was presented for $60 \mathrm{~min}$ in this case. Many backfilled cells were identified in HVo, portions of the lateral HV, NFl/lAN, and pBas (see Fig. 6A-D). Most of these cells also contained Zenk-labeled nuclei (see Fig. 6A-G). Labeled cells in $\mathrm{HV}$ were typically round or multipolar and usually exhibited staining throughout the nucleus (see Fig. 6E). Neurons in NFl were typically multipolar (see Fig. 6F). Many exhibited whole nuclear staining (see Fig. 6F), although some exhibited perinucleolar staining only (see Fig. 2B,C). Labeled cells in pBas were round or multipolar and typically exhibited whole nuclear staining (see Fig. 6G).

Figure 7 depicts the results of a BDA experiment in which a tracer injection was placed in NLs and auditory stimulation was presented for $30 \mathrm{~min}$ followed by a $60-\mathrm{min}$ rest period. Backfilled cells were observed in NFl, pBas, and the ventral HVo and NAo surrounds (see Fig. 7A-C). BDAlabeled cells in NFl were multipolar and many contained Zenk labeling throughout the nucleus, whereas others contained only perinucleolar label (see Fig. 7D-F). Many cell clusters in which all or most of the neurons contained Zenkstained nuclei were also observed in this case (see Fig. 7F). Ulinski $(1976,1983)$ has described the prominent cell clustering in the avian and reptilian dorsal ventricular ridge. Cell clusters usually contain three to six neurons, although larger clusters exist. Neurons in these clusters are apparently electrotonically coupled. Zenk-stained nuclei were often present in all or most of the neurons within such clusters (see arrow pointing to cell cluster in Fig. 7F).

Figure 8 depicts the results of a BDA experiment in

$$
\begin{array}{lllllllllllllll}
L & E & A & R & N & I & N & G & \mathcal{Z} & M & E & M & O & R & Y \\
\text { www.learnmem.org } & & &
\end{array}
$$


$\mathbf{A}$

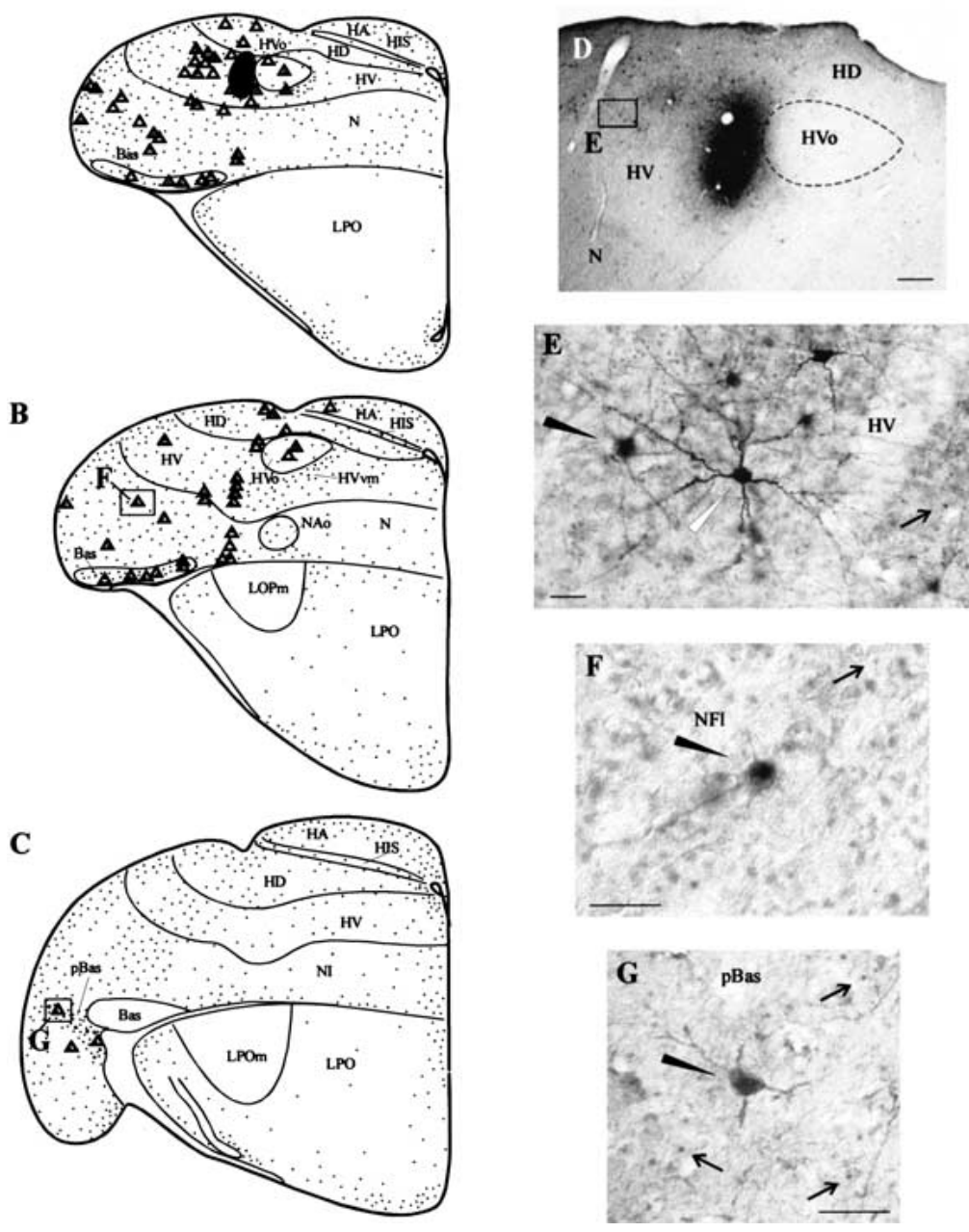

Figure 6 The results of a pathway tracing study in which BDA was injected into the lateral $\mathrm{HV}$ o surround. The subject was exposed to a repeating unfamiliar contact call for $60 \mathrm{~min}$ before being sacrificed. ( $A-C$ ) Schematic drawings in the transverse plane. In $A-C$, backfilled cells are indicated as triangles, double-labeled cells are indicated as triangles with small dots inside, and neurons expressing Zenk but not containing tracer are indicated as small dots. The injection site is indicated as a dark shaded area in $A$. As can be seen, many double-labeled cells were observed in the lateral HV, pBas, and NFI. (D) A low-power photograph of the injection site area. The boxed area marked " $E$ " in $D$ is featured in panel $E$, which depicts BDA and Zenk staining in HV. The solid arrowhead in $E$ points to a double-labeled cell. The white arrowhead points to a BDA-labeled cell that does not contain Zenk labeling. The arrow points to a neuron expressing Zenk but not containing BDA label. $(F, G)$ Photomicrographs illustrating $\mathrm{BDA}$ and Zenk staining in $\mathrm{NFI}$ and $\mathrm{pBas}$. The locations of the cells illustrated in $F$ and $G$ are indicated in boxed areas in $B$ and $C$. In both $F$ and $G$ black arrowheads point to double-labeled cells and black arrows point to neurons containing Zenk particles but not containing BDA. Scale bar in $D, 200 \mu \mathrm{m}$; scale bars in $E-G, 50 \mu \mathrm{m}$.

which the tracer was placed in the medial HVo and auditory stimulation was presented for $60 \mathrm{~min}$. Labeled neurons were observed in HVvm (see Fig. 8A-D), the medial neostriatum adjacent to NAo (8B) including NAom. Labeled cells in HVvm were generally smaller than those in NFL/lAN and the nuclei containing Zenk particles were observed to lie in positions closer to the cell membrane (see Fig. 8C,D). Overall, Zenk labeling was sparser than for the cases illustrated in Figures 7 and 8 . This may be because those HVvm neurons in these areas that project to $\mathrm{HVo}$ are much more closely related to the motor system than to the auditory system as discussed by Jarvis and Mello (2000) (see Discussion).

\section{DISCUSSION}

Contact calls induce the expression of the immediate early gene protein Zenk in telencephalic auditory pathways in the budgerigar. Two different staining patterns were induced in neuronal nuclei, staining throughout the nucleus and perinucleolar staining (see Fig. 3). In view of this, we considered the possibility that the antibody used here (Santa Cruz Biotec, SC-110) may be labeling more than one protein, perhaps ribosomal subunit proteins. Our immunoblot experiments (see Fig. 2A), however, and antibody preabsorption experiments (see Materials and Methods and Results) do not support this possibility but indicate that SC110 antibody is specific for avian Zenk protein.

Further evidence that the perinucleolar Zenk particles in neuronal nuclei (Fig. 2B,C) are not nucleoli is provided by comparing the structure and sizes of nucleoli with those of the perinucleolar Zenk particles. Even the smallest stained Zenk particles are larger than the nucleoli in the auditory areas under study. We found that nucleolar size, based on neutral red staining ( $n=25$ for each region) varied very little from region to region: $\mathrm{HVvm}=1.14 \mu \mathrm{m} ; \mathrm{NLs}=1.08 \mu \mathrm{m} ; \quad \mathrm{NFl}=1.16$ $\mu \mathrm{m} ; \mathrm{cBas}=1.18 \mu \mathrm{m} ; \mathrm{L} 1=1.2 \mu \mathrm{m} ; \mathrm{L} 2 \mathrm{a}=0.92$ $\mu \mathrm{m} ; \mathrm{L} 3=1.04 \mu \mathrm{m}$; and $\mathrm{NIVL}=0.96 \mu \mathrm{m}$. Because pBas has the largest nucleoli, we measured the Zenk particles in this region. Average Zenk particle size was $1.84 \mu \mathrm{m}(n=25)$. These results, taken in conjunction with the immunoblotting and blocking experiments, indicate that the small immunoreactive particles observed in the nuclei of some neurons represent a highly specific egr-1-binding pattern.

Previous studies using immunohistochemical methods have not reported different neuronal nuclear Zenk protein staining patterns (Ribiero et al. 1998; Herdegen and Leah 1998; Mello and Ribiero 1998). It is possible that perinucleolar expression of Zenk was weak in the species examined in previous studies and for this reason was not reported. Alternately, it is possible that differences in nuclear staining patterns for Zenk reflect spe-

$$
\begin{array}{lllllllllllllll} 
& E & A & R & N & I & N & G & \mathcal{Q} & M & E & M & O & R & Y \\
\text { www.learnmem.org } & & &
\end{array}
$$


$\mathbf{A}$

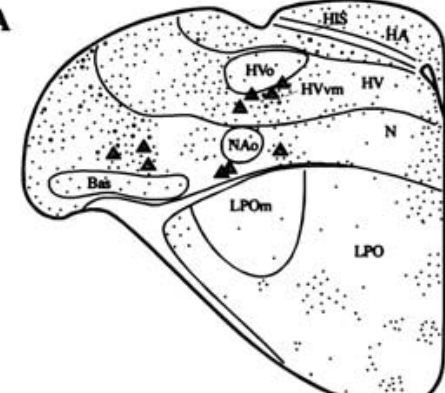

B
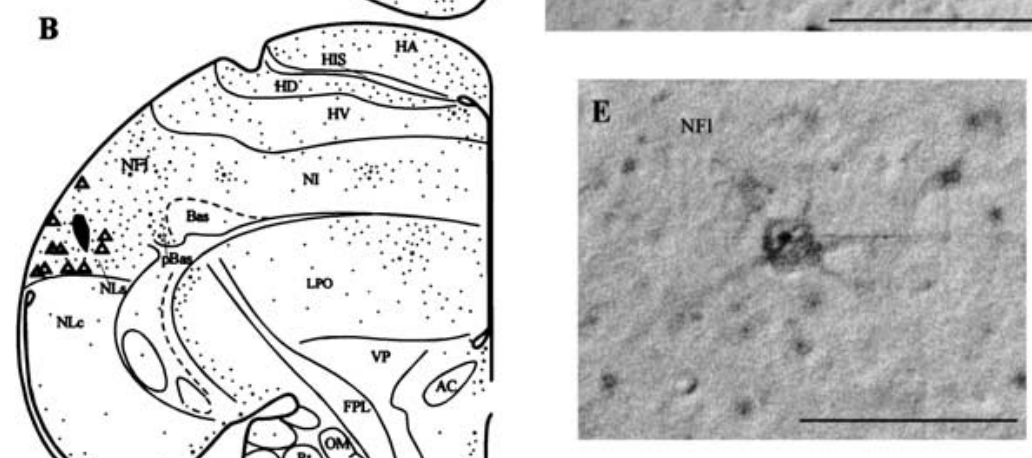

C

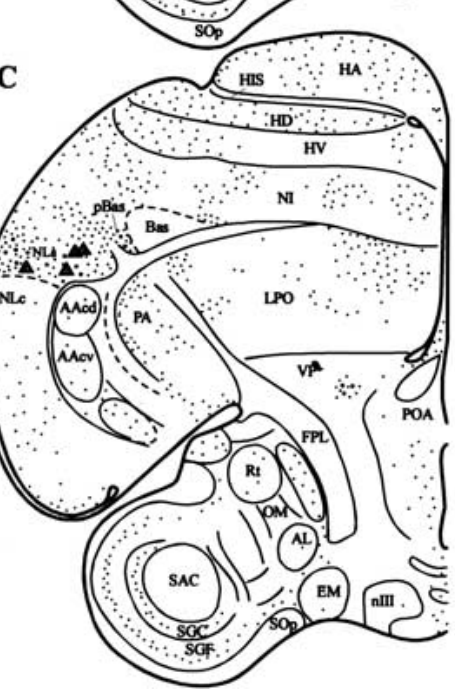

Figure 7 The results of a BDA experiment in which the tracer was injected into NLs and the subject was exposed to a repeating, unfamiliar contact call for $30 \mathrm{~min}$. ( $A-C$ ) Schematic drawings in rostrocaudal sequence indicating patterns of labeled and doublelabeled cells. The injection site is depicted as a dark shaded area in B. Many doublelabeled cells were observed in the $\mathrm{NFI}$, the anterior neostriatum, and the region ventromedial and ventral to HVo. Labeled cells in NFI are shown in $D$ and $E$. The cell pointed to by the black arrowhead in $D$ is shown at larger magnification in $E$. The arrow in $F$ points to cell clusters in NFI containing Zenk-positive nuclei. Scale bar in $D$ and $F, 100$ $\mu \mathrm{m}$. Scale bar in $E, 50 \mu \mathrm{m}$.

cies-specific activation patterns attributable to contact call stimulation that may not be present in songbirds. Different nuclear staining patterns in budgerigars may reflect the fact that Zenk competes with other transcriptional regulators, such as $s p 1$, at the promoters of some genes in some neurons. Additionally, it seems plausible that fewer genes are being regulated by egr-1 in those neurons that exhibit perinucleolar staining only.

The functional significance of the existence of the two staining patterns observed here in the budgerigar brain cannot be specified at present because it is as yet unclear which target genes are activated or repressed by Zenk in the avian brain (Clayton 2000). Nevertheless, this finding has potential implications for the study of learning and memory. It is generally believed that Zenk can mediate long-term changes in neuronal gene expression by coupling a variety of extracellular signals to gene transcription (Liu et al. 2000; Clayton 2000). Therefore, it would seem likely that the two patterns of nuclear Zenk protein expression also differ in terms of their efficacy to bring about the kinds of long-term cellular changes underlying neuronal plasticity.

\section{Overall Distribution of Zenk Protein in the Auditory System}

The pattern of neurons expressing Zenk protein in the caudal telencephalon is shown in Figure 3. These results are similar to that of the warble song-driven mRNA induction described by Jarvis and Mello (2000) with the exception of labeling in L2a and NIVL. As in the Jarvis and Mello (2000) study, we observed a patchy distribution of Zenk protein within a broad zone encompassing $\mathrm{L} 1$ and $\mathrm{L} 3$ as well as areas dorsal and ventral to L1 and L2 and a zone encompassing areas dorsal and ventral to L2b (see Fig. 3). We also observed Zenk protein label in a third zone including NIVL and areas dorsal and ventral to NIVL.

Jarvis and Mello (2000) did not observe significant zenk mRNA label in L2a in budgerigars. This is consistent with work in songbirds (Mello et al. 1992; Mello and Clayton 1994) and hummingbirds (Jarvis et al. 2000), which also show that L2a expresses little, if any, zenk mRNA in response to auditory stimulation with song. In our material, L2a contains only small perinucleolar Zenk particles, however, the results of the induction and habituation ex-

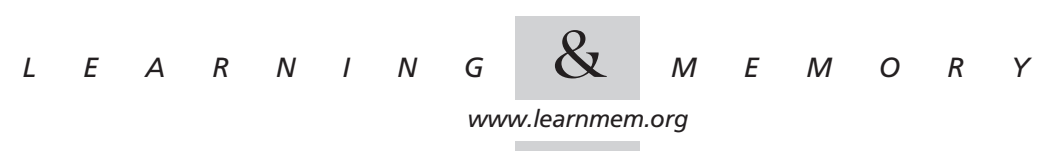



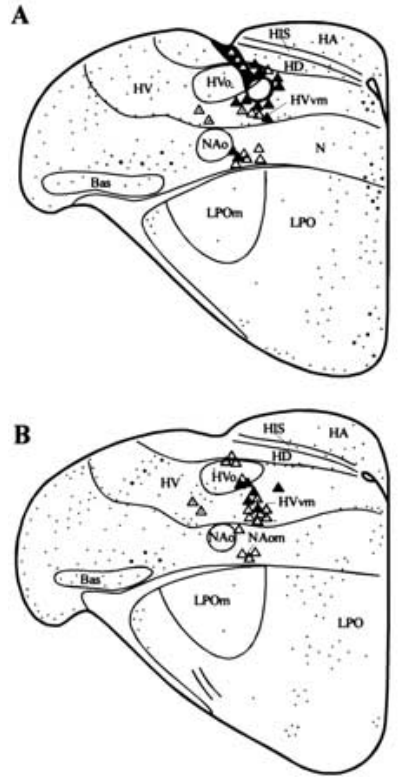

Figure 8 The results of a BDA experiment in which the tracer was injected into the medial HVo and the subject was exposed to a repeating contact call for $60 \mathrm{~min}$. (A,B) Line drawings illustrating patterns of Zenk staining and retrograde labeling. The injection site is shown as a dark shaded area in $A$. The tracer spread was confined to HVo because of the formation of a hole in the base of the pipette track. Doublelabeled cells were observed in HVvm and in the lateral HVo surround. Many unlabeled cells were also observed in the medial neostriatum. $(C, D)$ are photomicrographs illustrating retrogradely labeled cells in $\mathrm{HVvm}(C)$ and two double-labeled cells $(D)$. Scale bar in $C, 200 \mu \mathrm{m}$. Scale bar in $D, 50 \mu \mathrm{m}$.

periments (see Fig. 5) show that Zenk expression in L2a is induced by contact call stimulation. zenk mRNA expression in L2a may have been too low to detect in the Jarvis and Mello (2000) experiment.

Alternately, differences between the current study and Jarvis and Mello (2000) may reflect methodological differences. The current study examined Zenk protein induction in response to contact calls using protein immunohistochemistry, while Jarvis and Mello (2000) examined zenk mRNA (probe directed against canary zenk mRNA) induction in response to warble song stimulation. Once IEG mRNA is translated into protein, the protein enters the nucleus to regulate transcription of late response genes. The different staining patterns for Zenk protein induced by contact calls raises the intriguing possibility that Zenk controls the transcription of different subsets of genes in different telencephalic nuclei. The genes that are being regulated by Zenk in vivo are not yet known.

Pathway tracing experiments (Brauth et al. 1987, 1994; Brauth and McHale 1988) have shown that the L1-L2a-L3 complex is associated with auditory input relayed from the primary auditory thalamic nucleus, nucleus ovoidalis, to L2a (Hall et al. 1993; Brauth et al. 2001). The fields located dorsal and ventral to L2a (i.e., L1 and L3), which extend into the overlying and underlying neostriatum are functionally related to this system in birds (Wild et al. 1993). Therefore, the induction and habituation of Zenk protein in these areas, indicates that novel stimuli engender IEG protein synthesis. Whether such genomic activity is related to learning or to other processes related to perception, such as attention, cannot be stated at present.

L2b receives input from a different auditory thalamic nucleus, nucleus semiluminaris parovoidalis (Wild et al. 1993; Brauth et al. 1994). It therefore seems likely that areas of the neostriatum located within the band of Zenk+ neurons ventral and dorsal to L2b are also functionally related to the auditory system, although these fields have not been found to receive or provide input to the vocal control system (Durand et al. 1997; Brauth et al. 2001). Nevertheless, neurons in these fields may be involved in the processing of complex auditory stimuli.

As shown in Figure 5, NIVL neurons exhibit significant Zenk protein induction compared with controls. Previous studies have shown that NIVL receives input from Fields L1 and L3 (Brauth and McHale 1988; Wild and Farabaugh 1997) and projects to the medial neostriatum, including HVvm (Hall et al. 1993; Brauth et al. 2001). Jarvis and Mello (2000) did not observe significant zenk mRNA expression in NIVL or in the anterior auditory areas including NLs, NFl/1AN, or HVvm. These discrepancies are difficult to interpret at present but may be related to the fact that Jarvis and Mello (2000) used warble as a stimulus in the presence of both other birds and the experimenter (who acted to inhibit vocalization), whereas contact call stimuli in the absence of other birds or the experimenters was used in this study. Because context can strongly affect Zenk expression (Jarvis et al. 1998), it is possible that these differences in Zenk expression may be related to either the stimulus used or to the context in which the stimulation was provided.

Jarvis and Mello (2000) observed strong zenk mRNA expression in a large area they called the "HVo complex," located ventral and medial to HVo and including the ventromedial part of the $\mathrm{HV}$ ( $\mathrm{HVvm}$ ), when budgerigars warbled, but not when budgerigars passively listened to warble song. In this study, we observed Zenk protein induction in HVvm in response to contact call stimulation. Most HVvm neurons expressing contact call-driven Zenk protein induction, however, exhibited perinucleolar labeling (see Fig. 8). These results, in conjunction with those of Jarvis and Mello (2000), indicate that although auditory stimulation can evoke perinucleolar zenk gene protein expression in HVvm, it may not yield high enough overall

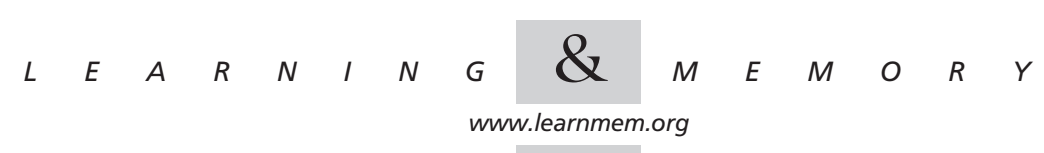


levels of mRNA expression to produce whole nuclear labeling in most neurons. Additional experiments are needed to evaluate this possibility.

Strong Zenk protein expression was observed here in NFl (lAN), NLs, and pBas, all of which are closely related to auditory-vocal pathways (see Fig. 1) (Hall et al. 1993; Durand et al. 1994; Striedter 1994; Farabaugh and Wild 1997; Brauth et al. 2001). Familiarization of the birds with the contact call stimulus resulted in significant habituation of these responses (see Fig. 5B). In view of the fact that anatomical connections exist between neurons in these areas and vocal control nuclei, it is tempting to speculate that in these neurons, egr-1 couples auditory stimulation to the synthesis of proteins involved in either the storing new perceptual engrams for vocal learning or the processing of novel and/or meaningful acoustic stimuli that are related either to vocal learning or the context in which vocal learning occurs.

\section{Pathway Tracing Studies}

The results of the pathway tracing studies indicate that many neurons in NFl, HVvm, pBas, and NLs that express Zenk are projection neurons that provide input to portions of HVo, the lateral and medial HVo surround, and NLs (see Figs. 6-8). Double-labeled neurons in these areas were not observed in control cases, in which only scattered Zenk particles were present in the anterior telencephalon. This indicates that the dextran amines label does not by itself induce Zenk expression. In all areas except HVvm, many neurons exhibited whole nuclear Zenk staining. As stated above, most HVvm neurons exhibited perinucleolar staining. Furthermore, double-labeling patterns in HVvm were observed to differ, depending on the tracer injection site. Only very few HVvm neurons projecting to HVo express contact call-driven Zenk protein (see Fig. 8), whereas many neurons in HVvm that project to NLs express contact calldriven Zenk protein (see Fig. 7).

In addition to the above observations, it is also notable that retrogradely labeled cells in all pathway tracing experiments were typically found in isolation (see Figs. 6E-G, 7D-F, and 8D) despite the fact that the avian neostriatum and hyperstriatum are composed of neurons arranged in cell clusters (Ulinski 1983) (see also Fig. 7F). It is not clear if the unlabeled neurons in these clusters are projection neurons whose axons project to other targets or if any of these unlabeled cells are interneurons.

Many double-labeled neurons were observed in portions of the lateral and ventral $\mathrm{HV}$ in cases in which tracer was placed in HVo (see Fig. 8) or the lateral HVo surround (see Fig. 6). Neurons in these areas have been shown to receive input from NLs (Brauth et al. 2001) and from the lateral neostriatum intermedium (NIL). In birds, NIL receives input from many sensory streams in birds (Kröner and Güntürkün 1999; Brauth et al. 2001) and has been com- pared with portions of the mammalian prefrontal cortex (Kröner and Güntürkün 1999). Inputs to NIL in the budgerigar include Field L3, NIVL, Bas, and the periectostriatal belt (Brauth et al. 2001). The latter structure is a higherorder structure related to the visual system (Butler and Hodos 1996). The presence of double-labeled cells in the HV in cases in which the tracer was placed in HVo (see Fig. 8) or the lateral HVo surround (see Fig. 6) raises the interesting possibility that these inputs are associated with processing stimuli related to the context in which auditory and/or vocal learning occur.

\section{Conclusions}

The existence of rapid Zenk protein induction in those nuclei of the budgerigar auditory system closely related to the vocal system is consistent with the hypothesis that in these neurons, egr-1 couples auditory stimulation to the synthesis of proteins involved either in storing auditory engrams or processing novel and/or meaningful acoustic stimuli related to vocal learning. Herdegen and Lea (1998) noted that exogenous novel stimuli may initiate intracellular cascades resulting in the production of IEGs, which act to sustain protein synthesis. Clayton (2000) has called the wave of genomic activity coupled to IEG activation the "genomic action potential," which can produce diverse and long-lasting cellular effects. For example, in the zebra finch, Stripling et al. (1997) point out that in NCM, single-unit electrophysiological responses begin to habituate after one presentation of novel song stimuli, whereas the genomic response habituates over a period of minutes or hours. This hypothesis is also supported by our observation that Zenk induction in auditory nuclei habituates when the birds are familiarized with the call stimulus. Additional experiments, such as determination of the genes regulated by egr- 1 in budgerigars, as well as experiments assessing the effects of manipulating the acoustic properties of stimuli and the context in which stimulation occurs on Zenk induction are needed to test this hypothesis. This study is intended to set the stage for future such studies.

\section{MATERIALS AND METHODS}

\section{Subjects}

Eleen subjects were used in this study. Of these, six were used for both pathway tracing and anti-Zenk immunohistochemistry and two were used for quantitative immunoblotting. All subjects were bred in our laboratory and lived in a large, free-flight aviary containing from 50-70 other budgerigars in an enclosed portion (ceiling to floor) of an animal care room providing $\sim 22.8 \mathrm{~m}^{3}$ within which the birds could fly and interact. Birds were maintained on a controlled diet of seed, nuts, fruit, vegetables, and dairy products. Hardwood tree limbs affixed to the walls of the room afforded opportunities for perching. All procedures were approved by the campus animal care and use committee.

\section{Procedures for Contact Call Stimulation}

In these experiments, a repeating contact call was used as an au-

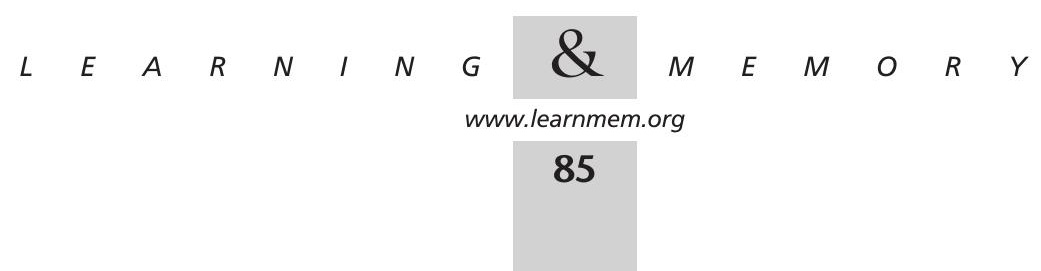


ditory stimulus (see below). Contact calls are short (150-250 msec) sounds produced when birds familiar with one another (male or female) are briefly separated, yet remain in visible or audible contact. Previous work has shown that both the spectral and temporal components of contact calls are learned during social interactions with other birds (Brown et al. 1988; Farabaugh et al. 1994; Hile et al. 2000) through processes requiring auditory feedback (Dooling et al. 1987; Heaton and Brauth 1999; Heaton et al. 1999), which are mediated by specialized telencephalic vocal control nuclei (Brauth et al. 1997; Heaton and Brauth 2000a,b; Lavenex 2000).

Two procedures for auditory stimulation were used. In the first procedure, five subjects were individually placed in Plexiglas sound attenuated chambers lined with acoustic foam (Heaton and Brauth 2000) and allowed to rest quietly overnight. At the end of the rest period, two subjects (controls) were immediately anesthetized and the brains perfused and fixed for anti-Zenk immunohistochemistry as described below. The remaining subjects were stimulated by playbacks of a single, repeating unfamiliar contact call (228 msec call, 0.5 calls/sec) for $30(n=2)$ or $60(n=3) \mathrm{min}$. This call had been recorded previously from a bird who had lived in the laboratory $7 \mathrm{yr}$ before and whose call was, therefore, not shared by any of the birds used in the current experiment. Subjects stimulated for $30 \mathrm{~min}$ were subsequently allowed to rest for an additional $60 \mathrm{~min}$ in the quiet to allow time for protein translation before perfusion. These stimulation parameters were chosen to determine if relatively brief exposure to the stimulus could rapidly induce Zenk protein in auditory areas. Subjects exposed to $60 \mathrm{~min}$ of stimulus were quickly anesthetized and perfused after stimulation as described below.

In the second procedure, three additional subjects were individually placed in Plexiglas chambers and presented with the same repeating unfamiliar call for $24 \mathrm{~h}$ to familiarize each of them with the call stimulus. The subjects were then rested quietly for $24 \mathrm{~h}$ individually in the chambers to ensure that baseline levels of Zenk expression were present in the brain. After this period, the subjects were stimulated for $60 \mathrm{~min}$ with repeated playbacks of the same unfamiliar call. The birds were then deeply anesthetized, perfused, and the brain tissue fixed using the procedures described below.

The first procedure was designed to determine which auditory nuclei exhibit significant zenk gene protein expression in response to contact call stimulation. The second procedure was designed to determine if habituation of zenk gene protein induction to a previously novel stimulus occurs in auditory neurons and if such habituation persists over a $24-\mathrm{h}$ period.

All subjects were monitored unobtrusively by the technician during the stimulation period to verify that the subjects did not vocalize. An advantage of the procedure used in the present study over stimulation with live birds is that we have found that budgerigars only rarely call back to a repeating contact call when they cannot see live birds or hear more varied calls produced by groups of live birds. Therefore, the method employed in this study avoids additional auditory stimulation from self-produced calls, ensures that all birds in all experiments hear the same stimulus under the same conditions, and prevents vocalization-driven gene expression.

At the end of the experiment, subjects were anesthetized with sodium pentobarbital $(9 \mathrm{mg} /$ bird in $0.20 \mathrm{~mL}$ saline, i.m.), the chest opened and cannulae inserted into one or both carotid arteries. Perfusion with saline was followed by a $4 \%$ buffered paraformaldehyde fixative and the brain tissue removed from the skull and blocked stereotaxially. The brains were then stored in sodium phosphate buffered saline (PBS) $(0.1 \mathrm{M} ; \mathrm{pH}=7.2)$ with $30 \%$ sucrose overnight, sectioned at $40 \mu \mathrm{m}$ on a sliding freezing microtome and processed histochemically as described below for immunohistochemistry as described below.

\section{Quantitative immunoblotting}

Tissue was harvested from two birds for biochemical analysis $1 \mathrm{~h}$ following the onset of stimulation with a repeating unfamiliar contact call. Cytoplasmic proteins were prepared as described previously (Liu et al. 2000). Tissue blocks were collected in ice-cold dissection buffer containing $2.6 \mathrm{mM} \mathrm{KCl}, 1.23 \mathrm{mM} \mathrm{NaH}_{2} \mathrm{PO}_{4}$, and $26 \mathrm{mM} \mathrm{NaHCO}$. Tissue blocks were obtained from the caudal telencephalon, including the field $\mathrm{L}$ nuclei and were immediately homogenized in ice-cold lysis buffer (20 mM HEPES pH 7.5, 150 $\mathrm{mM} \mathrm{NaCl}, 1 \% \mathrm{NP}-40,0.1 \% \mathrm{SDS}, 1 \mathrm{mM}$ EDTA, $50 \mathrm{mM}$ sodium fluoride, $2 \mathrm{mM}$ sodium vanadate, $1 \mathrm{mM}$ dithiothreitol, $0.5 \mathrm{mM}$ phenylmethylsulfonyl fluoride, and a protease inhibitor cocktail) in a glass/glass tissue homogenizer (Kontes, Vineland, NJ). Protein extracts (10-80 $\mu \mathrm{g} / \mathrm{lane})$ were resolved on $10 \%$ polyacrylamide gels, transferred to nitrocellulose and probed with an anti-egr-1(SantaCruz Biotec., SC-110) antibody, followed by the appropriate secondary antibody coupled to horseradish peroxidase (1:3500, Sigma Immunochemicals) in Tris-buffered saline ( $\mathrm{pH}=7.3$ ) containing $1 \%$ bovine serum albumin and $0.1 \%$ Triton $\mathrm{X}-100$. Visualization of immunoreactive bands was induced by enhanced chemiluminescence (Amersham ECL) captured on autoradiography film (Amersham Hyper ECL). Digital images, produced by densitometric scans of autoradiographs on a ScanJet IIcx (Hewlett Packard) with DeskScan II software (Hewlett Packard).

\section{Pathway Tracing and Zenk Immunohistochemistry}

Six birds were used in pathway tracing experiments to determine if neurons projecting to the HVo, its surround, or NLs express Zenk protein under the conditions of the experiment. Two of the pathway tracing cases involved Zenk control subjects and four involved injections in the HVo surround (three cases) and NLs (one case). Results from two of these cases (one BDA injection in NLs and one $\mathrm{BDA}$ injection in the lateral HVo surround) were used in a previous pathway tracing study (Brauth et al. 2001).

In all pathway tracing cases, subjects were weighed and anesthetized with ketamine ( $40 \mathrm{mg} / \mathrm{kg}$, i.m.) and xylazine $(12 \mathrm{mg} / \mathrm{kg}$, i.m.), feathers plucked from the neck and betadine applied to the skin. For neurosurgery, the birds were placed in a Kopf small animal stereotaxic instrument with the bill tip positioned $5 \mathrm{~mm}$ below the interaural line. The skull was opened with a dental turbine drill and the dura incised with a dura hook. Small quantities (5-15 nl) of tracer consisting of $10 \%-15 \%$ biotinylated dextran amines (BDA) in saline were injected through a glass pipette attached to a $1.0 \mu \mathrm{L}$ Hamilton syringe. Wounds were closed with nexaband and the birds allowed to recover in a warm chamber. If deemed necessary, yohimbine $(0.275 \mathrm{mg} / \mathrm{kg})$ was used to speed recovery from xylazine anesthesia. Subjects survived for $4 \mathrm{~d}$ after which time they were exposed to auditory stimulation (60 min of a repeating contact call or 30 min of stimulation followed by a 60 -min rest), deeply anesthetized, and perfused as described above.

To prepare double-stained sections suitable for viewing in transmitted light, the tissue was first processed for BDA using the avidin-biotin method with diaminobenzidine (DAB) as the chromogen. For subsequent Zenk immunohistochemistry, the sections were incubated for $1 \mathrm{hr}$ in PBS $(0.1 \mathrm{M}$; $\mathrm{pH}=7.4)$ with $10 \%$ normal goat serum (NGS), washed and transferred to a solution of primary rabbit anti-Zenk serum (Santa Cruz Biotech, sc-110) diluted 1:1000

\section{$\begin{array}{lllllllllllllllllllllllll}L & E & A & R & N & I & N & G & \& & M & E & M & O & R & Y\end{array}$}


in PBS with $0.5 \%$ Trition-X-100 and $4 \%$ NGS for $48-72 \mathrm{~h}$ at $4{ }^{\circ} \mathrm{C}$ under gentle agitation. The sections were then washed, incubated in a solution of biotinylated goat anti-rabbit serum diluted 1:200 with PBS for $1 \mathrm{~h}$, and stained using the blue SG or brown DAB chromogens (Vector Labs) via the $\mathrm{ABC}$ method. In one case, some control sections were treated with Zenk antiserum preabsorbed with Zenk antigen (Santa Cruz Biotech, sc-110) before use. No staining was observed on these sections. Other control sections were treated with Zenk antiserum preabsorbed with a peptide derived from the immediate early gene protein Sp-1 (Santa Cruz Biotech). Sp-1 may target the same DNA sequences as Zenk. (Lei and Heckert 2002). Preabsorption of the SC-110 antiserum, however, had no effect on staining of tissue sections. Therefore, our results reveal no cross reactivity between the SC-110 antibody and Sp-1.

\section{Unbiased Stereology}

Unbiased stereology was used to quantify Zenk protein expression in cell nuclei. To do this, slides were viewed with a $100 \times$ objective, $10 \times$ eyepiece, and $1.25 \times$ camera lucida using a Leitz Dialux microscope in which stage movement had been calibrated. Zenk particles were counted with the optical dissector method (Coggeshall and Lekan 1996) (dissector dimensions $=73 \mu \mathrm{m} \times 113 \mu \mathrm{m} \times 15$ $\mu \mathrm{m})$ by systematically sampling all parts of each nucleus under study. For each sample, the stage was lowered until the section came into focus, then lowered $5 \mu \mathrm{m}$ more. This was an exclusion plane. All particles that came into focus as the stage was lowered an additional $15 \mu \mathrm{m}$ were counted provided they did not touch either the upper or left sides of the box. The term "particles" is used in the stereological sense to refer to countable entities and does not imply anything about the size and shape of the entities being counted. Two observers performed each measurement to ensure that the data were reliable. The densities of labeled nuclei per cubic millimeter were then determined for each dissector and averaged across the entire structures sampled.

The structures for which Zenk protein expression was quantified in this report included Field L2a (the primary thalamo-telencephalic recipient area of field L), Field L1, Field L3, NIVL (neostriatum intermedium pars ventrolateralis), the supracentral area of the lateral neostriatum (NLs), the frontal lateral neostriatum $(\mathrm{NFl}=1 \mathrm{AN})$, the neostriatum immediately lateral to the caudal basalis (pBas), and the ventromedial hyperstriatum ventrale (HVvm). The nomenclature used here for L1, L2, and L3 is based on that of Müller and Leppelsack (1985), Müller and Scheich (1985), Scheich and Bonke (1981), and Wild et al. (1993). Wild (1987) described Field L2b as the primary thalamo-recipient zone for the thalamic nucleus semilumaris parovoidalis, a nucleus in receipt of input from nuclei of the lateral lemniscus. L2b is also labeled on the drawings. It should be noted that the structure labeled NFl on the figures and in the text in this report is equivalent to the structure designated the lateral nucleus of the anterior neostriatum (IAN) by Jarvis and Mello (2000).

\section{ACKNOWLEDGMENTS}

This research was supported by National Science Foundation grant IBN 16061 to SEB and in part by training grant MH-20048-01A1 from the National Institute of Mental Health to TFR.

The publication costs of this article were defrayed in part by payment of page charges. This article must therefore be hereby marked "advertisement" in accordance with 18 USC section 1734 solely to indicate this fact.

\section{REFERENCES}

Arends, J.J.A. and Zeigler, H.P. 1986. Anatomical identification of an auditory pathway from a nucleus of the lateral lemniscus to the frontal telencephalon (nucleus basalis) of the pigeon. Brain Res. 398: 375-381.

Bottjer, S.W., Meisner, A., and Arnold, A.P. 1984. Forebrain lesions disrupt development but not maintenance of song in passerine birds. Science 224: 901-903.

Brauth, S.E. and McHale, C.M. 1988. Auditory pathways in the budgerigar II. Intratelencephalic pathways. Brain Behav. Evol. 32: 193-207.

Brauth, S.E., McHale, C.M., Brasher, C.A., and Dooling, R.J. 1987. Auditory pathways in the budgerigar. I. Thalamo-telencephalic projections. Brain Behav. Evol. 30: 174-199.

Brauth, S.E., Heaton, J.T., Durand, S.E., Liang, W., and Hall, W.S. 1994. Functional anatomy of forebrain auditory pathways in the budgerigar (Melopsittacus undulatus). Brain Behav. Evol. 44: 210-233.

Brauth, S.E., Heaton, J.T., Shea, S.D., Durand, S.E., and Hall, W.S. 1997. Functional anatomy of forebrain vocal control pathways in the budgerigar (Melopsittacus undulatus). Annal. N.Y. Acad. Sci. 807: 368-385.

Brauth, S.E., Liang, W., and Roberts, T.F. 2001. Projections of the oval nucleus of the hyperstriatum ventrale in the budgerigar: Relationships with the auditory system. J. Comp. Neurol. 432: 481-511.

Brown, S.D., Dooling, R.J., and O'Grady, K. 1988. Perceptual organization of acoustic stimuli by budgerigars (Melopsittacus undulatus): III. Contact calls. J. Comp. Psychol. 102: 236-247.

Butler, A.B. and Hodos, W. 1996. Comparative vertebrate neuroanatomy: Evolution and adaptation. Wiley, New York, NY.

Clayton, D.H. 2000. The genomic action potential. Learning \& Mem. 74: 185-216.

Coggeshall, R.E. and Lekan, H.A. 1996. Methods for determining numbers of cells and synapses: A case for more uniform standards of review. $J$. Comp. Neurol. 364: 6-15.

Dooling, R.J., Gephart, B.F., Price, P.H., McHale, C., and Brauth, S.E. 1987. Effects of deafening on the contact call of the budgerigar (Melopsittacus undulatus). Animal Behav. 35: 1264-1266.

Durand, S.E., Heaton, J.T., Amateau, S., and Brauth, S.E. 1997. Vocal control pathways through the anterior forebrain of a parrot (Melopsittacus undulatus). J. Comp. Neurol. 377: 179-206.

Farabaugh, S.M. and Wild, J.M. 1997. Reciprocal connections between primary and secondary auditory pathways in the telencephalon of the budgerigar (Melopsittacus undulatus). Brain Res. 747: 18-25.

Farabaugh, S.M., Linzenbold, A., and Dooling, R.J. 1994. Vocal plasticity in budgerigars (Melopsittacus undulatus): Evidence for social factors in the learning of contact calls. J. Comp. Psychol. 108: 81-92.

Fortune, E.S. and Margoliash, D. 1995. Parallel pathways converge onto HVc and adjacent neostriatum of adult male zebra finches (Taeniopygia guttata). J. Comp. Neurol. 360: 413-441.

Gahr, M. 2000. Neural song control system of hummingbirds: comparison to swifts, vocal learning (Songbirds) and nonlearning (Suboscines) passerines, and vocal learning (Budgerigars) and nonlearning (Dove, owl, gull, quail, chicken) nonpasserines. J. Comp. Neurol. 426: $182-196$

Hall, W.S., Cohen, P.L., and Brauth, S.E. 1993. Auditory projections to the anterior telencephalon in the budgerigar (Melopsittacus undulatus). Brain Behav. Evol. 42: 97-116.

Heaton, J.T. and Brauth, S.E. 1999. Effects of deafening on the development of nestling and juvenile vocalizations in budgerigars (Melopsittacus undulatus). J. Comp. Psychol. 113: 314-320.

- 2000a. Effects of lesions of the central nucleus of the anterior archistriatum on contact call and warble song production in the Budgerigar (Melopssitacus undulatus). Neurobiol. Learning Memory 73: 207-242.

2000b. Telencephalic nuclei control late but not early nestling calls in the budgrigar. Behav. Brain Res. 109: 129-135.

Heaton, J.T., Dooling, R.J., and Farabaugh, S.M. 1999. Effect of deafening on the calls and warble song of adult budgerigars (Melopsittacus undulatus). J. Acoustical Soc. Amer. 105: 210-219.

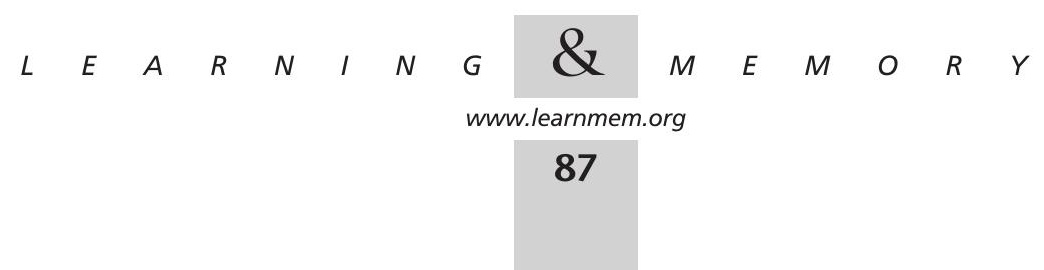


Herdegen, T.L. and Leah, J.D. 1998. Inducible and constitutive transcription factors in the mammalian nervous system: Control of gene expression by Jun, Fos and Krox, and CREB/ATF proteins. Brain Res. Rev. 28: 370-490.

Hile, A.G., Plummer, T.K., and Striedter, G.F. 2000. Male vocal imitation produces call convergence during pair bonding in budgerigars, Melopsittacus undulatus. Animal Behav. 59: 1209-1218.

Jarvis, E.D. and Mello, C. 2000. Molecular mapping of brain areas involved in parrot vocal communication. J. Comp. Neurol. 419: 1-31.

Jarvis, E.D., Mello, C., and Nottebohm, F. 1995. Associative learning and stimulus novelty influence the song-induced expression of an immediate early gene in the canary forebrain. Learning $\&$ Mem. 2: 62-80.

Jarvis, E.D., Ribeiro, S., da Silva, M.L., Ventura, D., Vielliard, J., and Mello, C.V. 2000. Behaviourally driven gene expression reveals song nuclei in hummingbird brain. Nature 406: 628-632.

Jarvis, E.D., Scharft, C., Grossman, M.P., Ramos, F.A., and Nottebohm, F 1998. For whom the bird sings: context-dependent gene expression. Neuron 21: 775-788.

Kaczmarek, L. and Chaudhuri, A. 1997. Sensory regulation of immediate-early gene expression in mammalian visual cortex: Implications for functional mapping and neural plasticity. Brain Res. Rev. 23: 237-256.

Karten, H.J. 1967. The organization of the ascending auditory pathway in the pigeon (Columba livia). I. Diencephalic projections of the inferior colliculus (nucleus mesencephali lateralis, pars dorsalis). Brain Res. 6: $409-427$.

Karten, H.J. 1968. The ascending auditory pathway in the pigeon (Columba livia). II. Telencephalic projections of the nucleus ovoidalis thalami. Brain Res. 11: 134-153.

Kelley, D.B. and Nottebohm, F. 1979. Projections of a telencephalic auditory nucleus-Field L-in the canary. J. Comp. Neurol. 183: $455-470$

Kröner, S. and Güntürkün, O. 1999. Affrent and efferent connections of the caudolateral neostriatum in the pigeon (Columba livia): A retroand anterograde pathway tracing study. J. Comp. Neurol. 407: 228-260.

Lavenex, P.B. 2000. Lesions in the budgerigar vocal control nucleus NLc affect production but not memory of English words and natural vocalizations. J. Comp. Neurol. 421: 437-460.

Lei, N. and Heckert, L.L. 2002. Sp1 and egr1 regulate transcription of the dmrt1 gene in sertoli cells. Biol. Reprod. 66: 675-684.

Lerea, L.S. 1997. Glutamate receptors and gene induction: Signaling from receptor to nucleus. Cell Signal 9: 219-228.

Liu, J., Tsai, J.C., and Aird, W.C. 2000. Egr-1 gene is induced by the systemic administration of the vascular endothelial growth factor and the epidermal growth factor. Blood 96: 1772-1781.

Mello, C.V., Vicario, D.S., and Clayton, D.F. 1992. Song presentation induces gene expression in the songbird forebrain. Proc. Natl. Acad. Sci. 89: 6818-6822.

Mello, C.V. and Clayton, D.F. 1994. Song-induced ZENK gene expression in auditory pathways of songbird brain and its relation to the song control system. J. Neurosci. 14: 6652-6666.

1995. Differential induction of the ZENK gene in the avian forebrain and song control circuit after metrazole-induced depolarization. J. Neurobiol. 26: 145-161.

Mello, C.V. and Ribeiro S. 1998. ZENK protein regulation by song in the brain of songbirds. J. Comp. Neurol. 393: 426-438.

Mello, C.V., Nottebohm, F., and Clayton, D.F. 1995. Repeated exposure to one song leads to a rapid and persistent decline in an immediate early gene's response to that song in zebra finch telencephalon. J. Neurosci. 15: 6919-6925.

O'Donovan, K.J., Tourtellotte, J.M., and Baaban, J.M. 1999. The EGR family of transcription-regulatory factors: Progress at the interface of molecular and systems neuroscience. Trends Neurosci. 22: 167-173.

Müller, S.C. and Scheich, H. 1985. Functional organization of the avian auditory field L=. A comparative 2DG study. J. Comp. Physiol. A 156: $1-12$.

Müller, C.M. and Leppelsack, H.J. 1985. Feature extraction and tonotopic organization in the avian auditory forebrain. Exp. Brain Res. 59: 587-599.

Ribiero, S., Cecchi, G.A., Magnasco, M.O., and Mello, C. 1998. Toward a song code: Evidence for a syllabic representation in the canary brain. Neuron 21: 359-371.

Scheich, H. and Bonke, B.A. 1981. Tone versus FM-induced patterns of excitation and suppression in the 14C-2-deoxyglucose labeled auditory cortex of the Guinea fowl. Exp. Brain Res. 44: 445-449.

Striedter, G. 1994. The vocal control pathways in budgerigars differ from those in songbirds. J. Comp. Neurol. 343: 35-56.

Stripling, R., Volman, S.F., and Clayton, D.F. 1997. Response modulation in the zebra finch neostriatum: Relationship to nuclear gene regulation. $J$. Neurosci. 17: 3883-3893.

Tischmeyer, W. and Grimm, R. 1999. Activation of immediate early genes and memory formation. Cell Mol. Life Sci. 55: 564-574.

Ulinski, P.S. 1976. Structure of anterior dorsal ventricular ridge in snakes. J. Morphol. 148: 1-22.

. 1983. Dorsal ventricular ridge. A treatise on forebrain organization in reptiles and birds, pp. 77-83. John Wiley and Sons, New York.

Vates, G.E., Broome, B.M., Mello, C.V., and Nottebohm, F. 1996 Auditory pathways of caudal telencephalon and their relation to the song system of adult male zebra finch (Taenopygia guttata). J. Comp. Neurol. 366: 613-642.

Waters, C.M., Hancock, D.C., and Evan, G.I. 1990. Identification and characterisation of the egr-1 gene product as an inducible, short-lived, nuclear phosphoprotein. Oncogene 5: 669-674.

Wild, J.M. 1987. Nuclei of the lateral lemniscus project directly to the thalamic auditory nuclei in the pigeon. Brain Res. 408: 303-307.

Wild, J.M. and Farabaugh, S.M.1996. Organization of afferent and efferent projections of the nucleus basalis prosencephali in a passerine, Taeniopygia guttata. J. Comp. Neurol. 365: 306-328.

Wild, J.M., Karten, H.J., and Frost, B.J. 1993 Connections of the auditory forebrain in the pigeon (Columba livia). J. Comp. Neurol. 57: 446-464.

Received April 27, 2001; accepted in revised form March 19, 2002. 


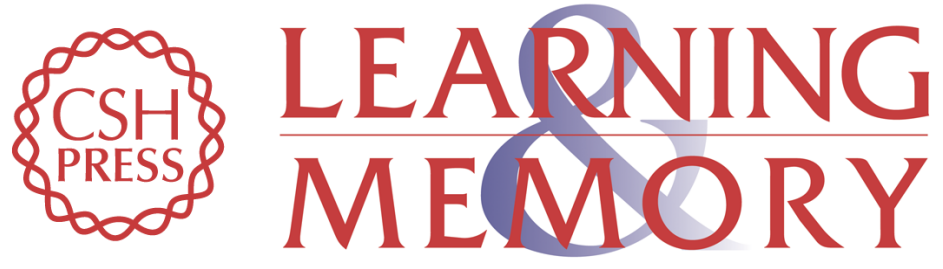

Contact Call-Driven Zenk Protein Induction and Habituation in Telencephalic Auditory Pathways in the Budgerigar ( Melopsittacus Undulatus ): Implications For Understanding Vocal Learning Processes

Steven Brauth, Wenru Liang, Todd F. Roberts, et al.

Learn. Mem. 2002, 9:

Access the most recent version at doi:10.1101//m.40802

References This article cites 50 articles, 6 of which can be accessed free at: http://learnmem.cshlp.org/content/9/2/76.full.html\#ref-list-1

License

Email Alerting Receive free email alerts when new articles cite this article - sign up in the box at the Service top right corner of the article or click here. 